\title{
PENINGKATAN PENGETAHUAN GURU MTS AL WASHLIYAH 19 PERCUT MENGENAI PEMENUHAN KEBUTUHAN GIZI BERBASIS PANGAN LOKAL
}

\author{
Wina Dyah Puspita Sari ${ }^{1^{*}}$, Erni Rukmana ${ }^{2}$, Hardi Firmansyah ${ }^{2}$, Risti Rosmiati ${ }^{2^{*}}$ \\ ${ }^{1}$ Program Studi Biologi, Fakultas Matematika dan Ilmu Pengetahuan Alam, \\ Universitas Negeri Medan \\ ${ }^{2}$ Program Studi Gizi, Fakultas Teknik, Universitas Negeri Medan \\ Email korespondensi: ristirosmiati@unimed.ac.id
}

Disubmit: 22 Oktober 2021

Diterima: 31 Desember 2021

Diterbitkan: 02 Januari 2022

DOI: https://doi.org/10.33024/jkpm.v1i1.5189

\begin{abstract}
ABSTRAK
Pemenuhan kebutuhan gizi berbasis pangan lokal merupakan implementasi dari panduan Pedoman Gizi Seimbang (PGS). Pemberian pengetahuan berkaitan dengan pemenuhan kebutuhan gizi pada guru dapat memberikan manfaat bagi lingkungan sekitar, terutama pada siswa di Sekolah. Tujuan kegiatan pengabdian kepada masyarakat ini adalah untuk meningkatkan pengetahuan guru tentang pemenuhan kebutuhan gizi berbasis pangan lokal. Kegiatan pengabdian berupa pendidikan gizi dengan metode ceramah dan diskusi kepada 15 orang guru MTs Al Washliyah 19 Percut. Adapun rincian kegiatannya adalah pembukaan, pre-test, penyampaian materi dan tanya jawab, post-test serta penutupan. Data preposttest dianalisis secara deskriptif dan uji beda paired $t$-test. Hasil analisis menunjukkan bahwa pengetahuan guru terkait pemenuhan kebutuhan gizi berbasis pangan lokal meningkat signifikan $(p<0,05)$. Berdasarkan hasil tersebut dapat disimpulkan bahwa pendidikan gizi efektif meningkatkan pengetahuan gizi guru MTs Al Washliyah 19 mengenai pemenuhan kebutuhan gizi berbasis pangan lokal.
\end{abstract}

Kata Kunci: Gizi seimbang, pangan lokal, pendidikan gizi

\begin{abstract}
Fulfillment of local food-based nutritional requirements is the implementation of the Guidelines for Balanced Nutrition (PGS). Efforts to increase teachers' knowledge about it can benefit their environment, especially for students. This community service activity aimed to increase MTs Al Washliyah 19 Percut teachers' knowledge about fulfilling local food-based nutritional requirements. The nutrition education for 15 teachers used the discussion method. The activities consist of opening, pre-test, material presentation and discussion, post-test, and closing session. The pre-posttest data were analyzed using the descriptive method and paired sample t-test. The results showed that teachers' knowledge regarding the fulfillment of local food-based nutritional requirements increased significantly $(p<0.05)$. Nutrition education effectively increases the knowledge of MTs Al Washliyah 19 teachers regarding the fulfillment of local food-based nutritional requirements.
\end{abstract}

Keywords: Balanced nutrition, local food, nutrition education 


\section{PENDAHULUAN}

Menciptakan Sumber Daya Manusia (SDM) yang berkualitas adalah tujuan pembangunan nasional. Di Indonesia, ada tiga beban masalah gizi (triple burden) yaitu stunting, wasting dan obesitas serta anemia. Prevalensi status gizi pada remaja siswa usia sekolah tahun 2018 adalah 25,7\% usia 13-15 tahun dengan kategori pendek dan 26,9\% remaja usia 16-18 tahun dengan kategori sangat pendek (Kementerian Kesehatan RI, 2019). Masalah gizi tersebut dapat mempengaruhi pembangunan nasional (Notoatmodjo, 2008). Gizi yang baik merupakan langkah penting dalam meningkatkan kesiapan siswa untuk belajar karena siswa yang bergizi baik dan sehat datang ke kelas secara mental dan fisik siap untuk belajar.

Pencapaian SDM yang berkualitas di lingkungan sekolah didapatkan dari Guru. Guru sebagai fasilator yaitu mengajar dan mendidik. Guru di sekolah memberikan informasi kepada siswa dan orang tuanya. Salah satu informasi tersebut adalah informasi gizi. Informasi gizi bertujuan untuk mendukung kesehatan dan meningkatkan pengetahuan tentang kebutuhan gizi seimbang (Contento, 2010; Cotton et al., 2020). Pemenuhan kebutuhan gizi disesuaikan dengan Pedoman Gizi Seimbang (PGS) saat ini.

Pemenuhan kebutuhan gizi berbasis pangan lokal merupakan implementasi dari panduan PGS. Panduan untuk memenuhi kebutuhan gizi seimbang harus disesuaikan dengan kelompok usia, jenis kelamin, dan kondisi khusus (ibu hamil, dan menyusui) (Kementerian Kesehatan RI, 2014). Slogan 4 sehat 5 sempurna masih melekat di masyarakat, pada hal slogan 4 sehat 5 sempurna tidak sesuai dengan kondisi dan permasalahan gizi saat ini (Kementerian Kesehatan RI, 2014). Pedoman gizi seimbang perlu diperkenalkan kepada siswa dan guru. Pendidikan gizi merupakan salah cara untuk memperkenalkan pedoman gizi seimbang.

Pemberian pengetahuan berkaitan dengan pemenuhan kebutuhan gizi pada guru dapat memberikan manfaat lingkungan sekitar, terutama pada siswa di Sekolah. Pengetahuan dan pemahaman gizi mempengaruhi cara memilih makanan. Pemilihan makanan didasarkan juga oleh preferensi makanan atau rasa suka dari makanan, budaya dan sosial, faktor kognitif-afektif dan pengaruh keluarga, genetik dan epigenetik pada karakteristik kepribadian. Penelitian yang dilakukan di Bogor pada Guru SMP didapatkan hasil yaitu 17,1\% pengetahuan gizi dengan kategori cukup (Soraya et al., 2017). Ini membuktikan bahwa masih ada guru yang belum paham terkait dengan pengetahuan gizi seimbang. Guru memiliki potensi untuk memainkan peran penting dalam upaya meningkatkan atau secara positif mempengaruhi perilaku pola makan siswa. Penelitian di Pontianak menunjukkan bahwa status gizi dan pola konsumsi anak akan meningkat dengan adanya peran dari guru dan orang tua (Ayu et al., 2020; Rahmiyah et al., 2016).

Kecamatan Percut Sei Tuan, merupakan Kecamatan di Sumatera Utara yang menghasilkan pangan lokal sumber protein yaitu ikan kembung, rata - rata hasil panen di tahun 2018 yakni sebesar 1.672,5 ton (Dinas Kelautan dan Perikanan Kabupaten Deli Serdang, 2020). Pangan lokal di daerah tersebut dapat memenuhi kebutuhan gizi seimbang. Peningkatan pengetahuan guru mengenai pemenuhan gizi berbasis pangan lokal sangat penting dilakukan.

Tujuan kegiatan pengabdian kepada masyarakat ini adalah untuk meningkatkan pengetahuan gizi guru tentang pemenuhan kebutuhan gizi berbasis pangan lokal. Setelah mengikuti kegiatan ini diharapkan para guru dapat menyampaikan pengetahuan tersebut kepada para siswa di MTs Al Washliyah 19 ataupun masyarakat umum di lingkungan sekitarnya. 


\section{MASALAH}

Data Riskesdas tahun 2018 menunjukkan bahwa remaja usia 13-15 tahun yang merupakan usia umum siswa SMP/MTs di Kabupaten Deli Serdang mengalami masalah gizi berlebih (gemuk dan obesitas) sekitar 13,50\% dan masalah gizi kurang (kurus dan sangat kurus) sebesar 10,77\%. Salah satu upaya untuk mengurangi prevalensi tersebut adalah dengan memberikan pengetahuan terkait cara pemenuhan kebutuhan gizi dengan memanfaatkan pangan lokal kepada remaja tersebut melalui guru sekolahnya. MTs Alwashliyah 19 Percut merupakan salah satu sekolah swasta di Kabupaten Deli Serdang yang berlokasi tidak jauh dari Universitas Negeri Medan. Guru-guru yang mengajar di sekolah tersebut belum pernah mendapatkan pelatihan terkait cara pemenuhan kebutuhan gizi berbasis pangan lokal.

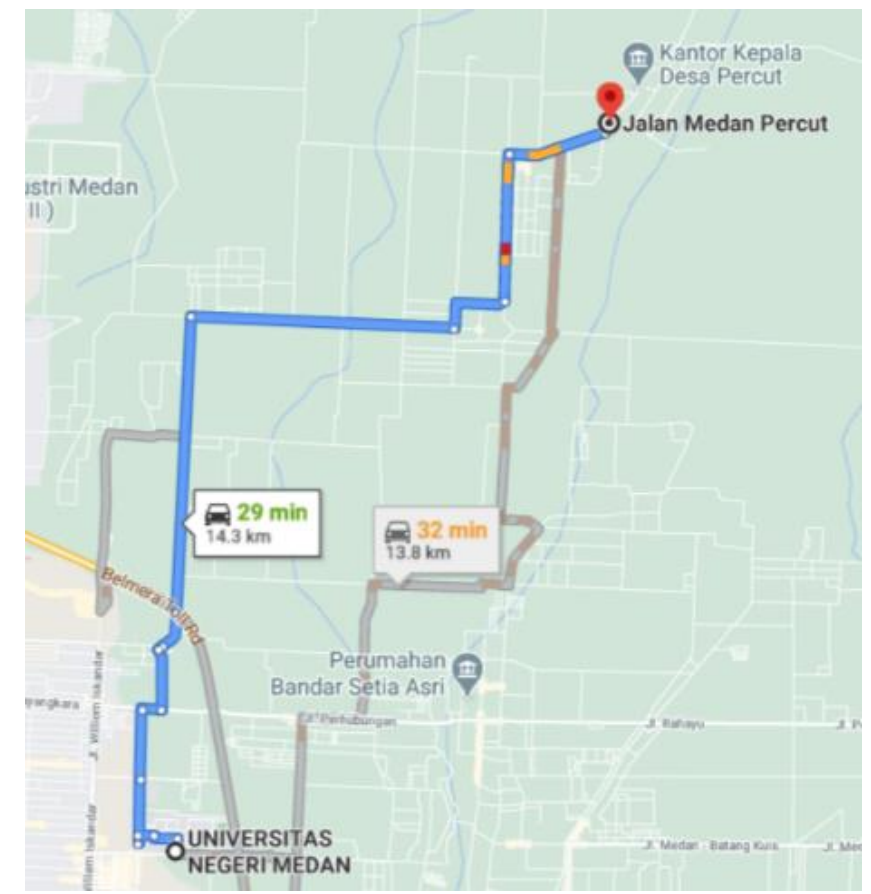

Gambar 2.1 Peta Lokasi Kegiatan Pengbdian Kepada Masyarakat

\section{METODE}

\section{a. Persiapan}

Persiapan yang dilakukan sebelum kegiatan pengabdian dialakukan diantaranya penyusunan rencana waktu pelaksanaan, persiapan alat dan bahan kegiatan, media pendidikan gizi yang akan digunakan serta koordinasi dengan pihak MTs Al Washliyah 19 Percut melalui kepala sekolahnya. Kegiatan pendidikan gizi menggunakan alat bantu video dan power point serta beberapa alat dan bahan penunjang seperti laptop, proyektor, pointer, alat tulis, lembar pre-posttest serta alat dokumentasi.

\section{b. Pelaksanaan}

Kegiatan pengabdian kepada masyarakat yang dilakukan adalah pendidikan gizi mengenai pemenuhan kebutuhan gizi berbasis pangan lokal. Kegiatan Pendidikan gizi ini dilakukan oleh dosen dan mahasiswa Program Studi Gizi dan Biologi yang memiliki kompetensi dibidang gizi masyarakat. Kegiatan pengabdian ini dilakukan terhadap 15 orang guru MTs Al Washliyah 19 di 
Desa Percut, Percut Sei Tuan, Deli Serdang pada Selasa, 6 Juli 2021 di MTs Al Washliyah 19 Percut.

Metode yang digunakan dalam kegiatan pengabdian kepada masyarakat ini adalah pendidikan gizi metode ceramah dan diskusi dengan bantuan media video dan Ms. Powerpoint. Kegiatan pendidikan gizi berlangsung dari pukul 10.00 - 12.00 WIB dengan rincian kegiatan yaitu pembukaan, pre-test, penyampaian materi dan tanya jawab, post-test serta penutupan. Data prepostest dianalisis secara deskriptif (rata-rata) dan diuji beda menggunakan paired t-test.

c. Evaluasi

\section{i. Struktur}

Peserta yang hadir sebanyak 15 orang guru MTs Al Washliyah 19 Percut. Kegiatan dilaksanakan di salah satu ruangan kelas dengan menerapkan protokol Kesehatan. Materi pendidikan gizi disusun menggunakan bahasa yang komunikatif dan mudah dipahami peserta. Guru-guru sangat antusias mengikuti kegiatan dan berpartisipasi aktif pada saat sesi diskusi serta mengisi pre-postest.

ii. Proses

Pelaksanaan kegiatan tanggal 6 Juli 2021 pukul 10.00-12.00 WIB. Sesuai dengan jadwal yang telah direncanakan.

\section{HASIL DAN PEMBAHASAN}

Kegiatan pendidikan gizi mengenai pemenuhan kebutuhan gizi berbasis pangan lokal dilakukan terhadap 15 orang guru MTs Al Washliyah 19 pada tanggal 6 Juli 2021 di salah satu ruangan kelas MTs Al Washliyah. Kegiatan dibuka dengan perkenalan tim abdimas dari Universitas Negeri Medan kepada para guru. Selanjutnya, para guru diminta untuk mengisi lembar pre-test untuk mengetahui tingkat pengetahuan gizi guru mengenai pemenuhan kebutuhan gizi berbasis pangan lokal sebelum diberikan pendidikan gizi.

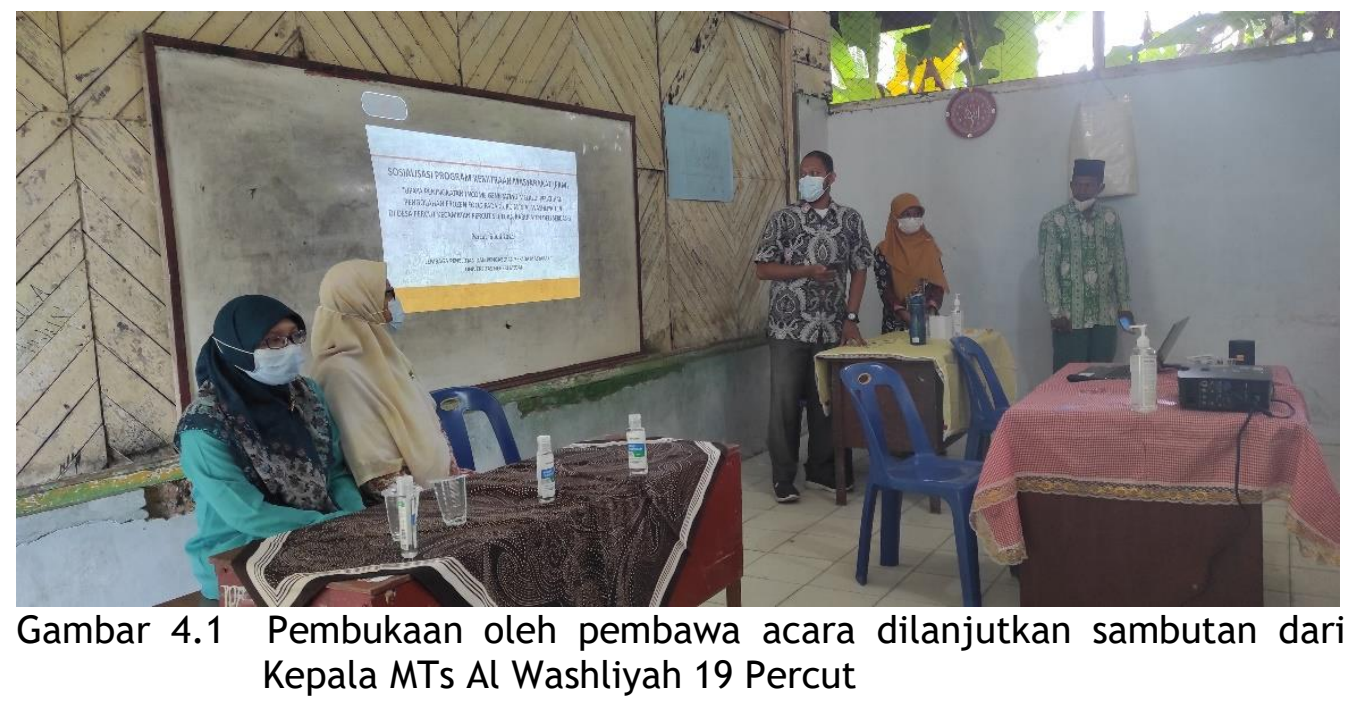

Tahapan berikutnya merupakan kegiatan utama yaitu pemberian materi dan tanya jawab terkait pemenuhan kebutuhan gizi berbasis pangan lokal yang dilakukan oleh tim abdimas. Untuk menganalisis adanya perubahan pengetahuan guru pada materi terkait maka dilakukan pos-test dengan soal yang sama dengan pre-test. Terakhir adalah penutupan kegiatan. 


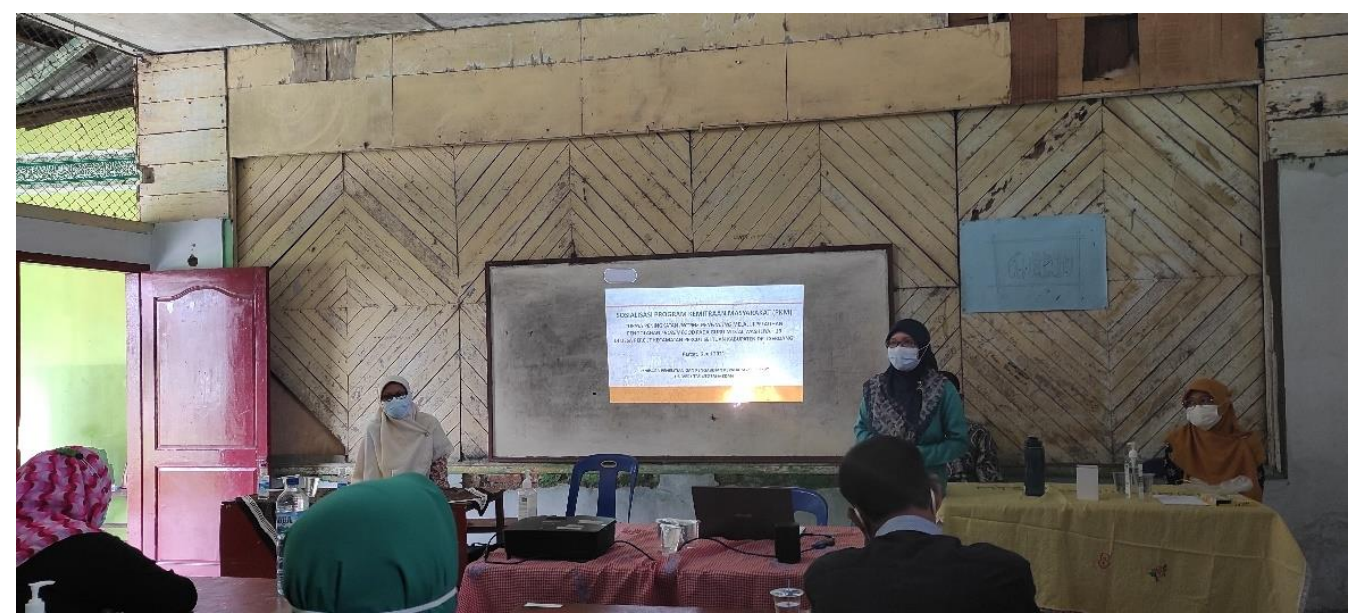

Gambar 4.2 Sambutan dan sosialisasi kegiatan oleh ketua pelaksana

Materi yang disampaikan pada kegiatan pendidikan gizi diantaranya keseimbangan energi yang dikonsumsi dan yang dibutuhkan tubuh, cara perhitungan dan cut off status gizi berdasarkan indeks masa tubuh (IMT), pedoman gizi seimbang, angka kecukupan gizi (AKG), kandungan gizi beberapa jenis pangan lokal yang tersedia dan mudah diperoleh serta penyusunan menu sesuai dengan kebutuhan yang memanfaatkan pangan lokal. Hasil pretestpostest ditunjukkan dalam Tabel 1.

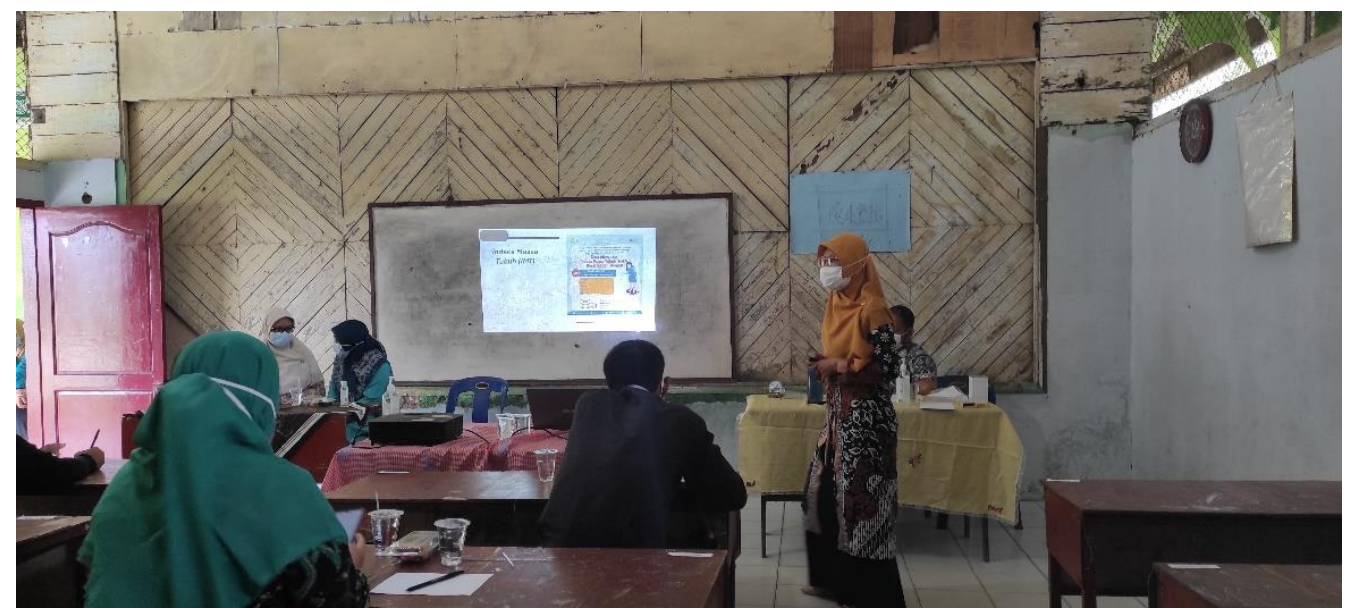

Gambar 4.3 Narasumber menyampaikan materi diawali dengan pretest

Tabel 1. Perubahan pengetahuan guru tentang pemenuhan kebutuhan gizi berbasis pangan lokal sebelum dan sesudah pendidikan gizi

\begin{tabular}{ccc}
\hline Waktu & Nilai Pengetahuan & P value \\
\hline Sebelum & $20.42 \pm 14.53$ & 0.000 \\
Setelah & $87.74 \pm 7.64$ & \\
\hline
\end{tabular}

Berdasarkan data pada Tabel 1 dapat diketahui bahwa pendidikan gizi secara signifikan dapat meningkatkan pengetahuan guru terkait pemenuhan kebutuhan gizi berbasis pangan lokal. Kegiatan pendidikan gizi telah terbukti dapat meningkatkan pengetahuan gizi (Komala \& Khodijah, 2017; Puspaningtyas et al., 2019; Zulaekah, 2012). 
Guru sebagai pendidik di sekolah diharapkan dapat menjadi perantara dalam upaya meningkatkan pengetahuan gizi terkati pemenuhan kebutuhan gizi berbasis pangan lokal pada anak sekolah. Penelitian sebelumnya menunjukkan bahwa pendidikan gizi pada guru dapat membantu meningkatkan asupan sayur dan buah anak sekolah (Silalahi et al., 2016, 2018) (Silalahi et al., 2018). Selain itu dukungan dari guru dalam kegiatan intervensi terkait gizi pada anak sekolah dapat meningkatkan kepatuhannya (Nuradhiani et al., 2017).

\section{KESIMPULAN}

Pendidikan gizi efektif meningkatkan pengetahuan guru MTs Al Washliyah 19 mengenai pemenuhan kebutuhan gizi berbasis pangan lokal.

\section{DAFTAR PUSTAKA}

Ayu, I. M., Nadiyah, N., Situngkir, D., \& Nitami, M. (2020). Program peningkatan pengetahuan kesehatan reproduksi remaja di SMK " $X$ " Tangerang Raya. Jurnal Kreativitas Pengabdian Kepada Masyarakat (PKM), 3(1), 87-95.

Cotton, W., Dudley, D., Peralta, L., \& Werkhoven, T. (2020). The effect of teacher-delivered nutrition education programs on elementary-aged students: An updated systematic review and meta-analysis. Preventive Medicine Reports, 20, 101178.

Dinas Kelautan dan Perikanan Kabupaten Deli Serdang. (2020). Statistik Perikanan Tangkap. Https: / /Diskanla.Deliserdangkab.Go.Id/Perikanan/Statistik/?Id=135.

Contento, I. R. (2010). Nutrition education: linking research, theory, and practice (2th ed.). Jones \& Bartlett Learning.

Kementerian Kesehatan RI. (2014). Pedoman Gizi Seimbang. Direktorat Bina Gizi dan KIA.

Kementerian Kesehatan RI. (2019). Laporan Nasional Riskesdas 2018. Lembaga Penerbit Badan Penelitian dan Pengembangan Kesehatan.

Komala, K., \& Khodijah, S. (2017). Penerapan program pendidikan gizi untuk meningkatkan pengetahuan gizi guru dan aplikasi pendidikan gizi untuk anak usia dini (Studi Kuasi Eksperimen pada Guru-Guru PAUD di Kota Cimahi dan Bandung Barat). Jurnal Ilmiah P2M STKIP Siliwangi, 4(1), 1620.

Notoatmodjo, S. (2008). Kesehatan dan Pembangunan Sumber Daya Manusia. Kesmas: Jurnal Kesehatan Masyarakat Nasional (National Public Health Journal), 2(5), 195-199.

Nuradhiani, A., Briawan, D., \& Dwiriani, C. M. (2017). Dukungan guru meningkatkan kepatuhan konsumsi tablet tambah darah pada remaja putri di Kota Bogor. Jurnal Gizi Dan Pangan, 12(3), 153-160.

Puspaningtyas, D. E., Sari, S. P., Afriani, Y., \& Mukarromah, N. (2019). Edukasi Gizi Efektif Meningkatkan Pengetahuan Atlet Mengenai Gizi Seimbang dan Pemenuhan Kebutuhan Cairan. Jurnal Pengabdian Dharma Bakti, 2(2), 34-38.

Rahmiyah, R., Budiastutik, I., \& Sutrisno, S. (2016). Hubungan Peran Guru Dan Orang Tua Dalam Pelaksanaan Pola Konsumsi Dengan Status Gizi Anak Usia Dini Di Raudhatul Atfal Jamiatul Khair Pontianak. Edukasi Jurnal IImiah Pendidikan Anak Usia Dini, 4(2), 129-135. 
Silalahi, V., Aritonang, E., \& Ashar, T. (2016). Potensi pendidikan gizi dalam meningkatkan asupan gizi pada remaja putri yang anemia di Kota Medan. KEMAS: Jurnal Kesehatan Masyarakat, 11(2), 295-301.

Silalahi, V., Putri, R. M. \& Ariani, N. L. (2018). Peranan Pendidikan Gizi pada Guru dalam Meningkatkan Asupan Sayur dan Buah Anak Sekolah. J. Ilm. Ilmu Kesehat, 6, 253-266.

Soraya, D., Sukandar, D., \& Sinaga, T. (2017). Hubungan pengetahuan gizi, tingkat kecukupan zat gizi, dan aktivitas fisik dengan status gizi pada guru SMP. Jurnal Gizi Indonesia (The Indonesian Journal of Nutrition), 6(1), 29-36.

Zulaekah, S. (2012). Pendidikan gizi dengan media booklet terhadap pengetahuan gizi. KEMAS: Jurnal Kesehatan Masyarakat, 7(2), 127-133. 